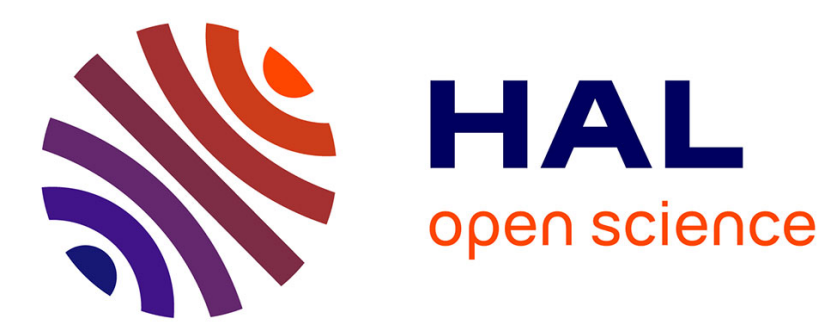

\title{
Biomechanical response of varicose veins to elastic compression: A numerical study.
}

Pierre-Yves Rohan, Pierre Badel, Bertrand Lun, Didier Rastel, Stéphane Avril

\section{To cite this version:}

Pierre-Yves Rohan, Pierre Badel, Bertrand Lun, Didier Rastel, Stéphane Avril. Biomechanical response of varicose veins to elastic compression: A numerical study.. Journal of Biomechanics, 2013, 46 (3), pp.599-603. 10.1016/j.jbiomech.2012.10.043 . hal-00801291

\section{HAL Id: hal-00801291 https://hal.science/hal-00801291}

Submitted on 15 Mar 2013

HAL is a multi-disciplinary open access archive for the deposit and dissemination of scientific research documents, whether they are published or not. The documents may come from teaching and research institutions in France or abroad, or from public or private research centers.
L'archive ouverte pluridisciplinaire HAL, est destinée au dépôt et à la diffusion de documents scientifiques de niveau recherche, publiés ou non, émanant des établissements d'enseignement et de recherche français ou étrangers, des laboratoires publics ou privés. 
2 Biomechanical response of varicose veins to

3 elastic compression: a numerical study

4

5 Rohan C.P-Y. ${ }^{1}$, Badel P. ${ }^{1}$, Lun B. ${ }^{2}$, Rastel D. ${ }^{3}$, Avril S. ${ }^{1}$

6

7

8

9

10

11

12

13

Word count (introduction through conclusion): 1988

Etienne, France

${ }^{2}$ Sigvaris Research and Development Center, Saint-Just-Saint-Rambert, France

${ }^{3}$ Vascular physician, Grenoble, France

Corresponding author:

Christian Pierre-Yves Rohan

Center for Health Engineering

Ecole Nationale Supérieure des Mines

158 cours Fauriel

42023 SAINT-ETIENNE CEDEX 2 France

Phone: +33477426609

Fax: +33477499755

Email: rohan@emse.fr

Stockings

${ }^{1}$ Ecole Nationale Supérieure des Mines de Saint-Etienne, CIS-EMSE, CNRS:UMR5307, LGF, F-42023 Saint

Keywords: Varicose veins; trans-mural pressure; Finite Element Updating; Medical Compression 


\section{Abstract}

27 A patient-specific Finite-Element (FE) model of the human leg is developed to model the stress distribution in and around a vein wall in order to determine the biomechanical response of varicose veins to compression treatment. The aim is to investigate the relationship between the local pressure on (the) soft tissues induced by wearing the compression garment and the development and evolution of varicose veins and various skin-related diseases such as varicose veins and ulcers. Because experimental data on the mechanical properties of healthy superficial veins and varicose veins are scarce in literature, ultrasound images of in vivo varicose veins are acquired and analysed to extract the material constants using Finite Element Model Updating. The decrease in trans-mural pressure, which conditions the effectiveness of compressive treatments, is computed from the simulation results. This constitutes the original added value of the developed model as decreases in trans-mural pressures cannot be assessed experimentally by any other means. Results show that external compression is effective in decreasing the trans-mural pressure, thereby having a positive effect in the control and treatment of vein-related diseases. 


\section{${ }_{41}$ Introduction}

42 Compression therapy by Medical Compression Stockings (MCS), which is considered as the "gold

43 standard" therapy for venous insufficiency, has been a topic of important research for 30 years. The

44 following effects or actions of MCS have gained a special interest:

45 - hemodynamic effects: (Mayberry et al., 1991), (Ibegbuna et al., 2003), (Guesdon et al., 2007), (Downie et 46 al., 2008) and (Wang et al., 2012), in continuation of pioneer studies on collapsible tubes: (Katz et al., 47 1969), (Moreno et al., 1970) and (Kamm and Shapiro, 1979);

48 - clinical and post-surgery effects: (Nehler et al., 1992), (Nehler et al., 1993)(Kern et al., 2007), 49 (Villavicencio, 2009) and (Hamel-Desnos et al., 2010);

50 - skin and deep tissue compression: (Wildin et al., 1998), (Agu et al., 1999), (Best et al., 2000), , (Yeung et 51 al., 2004), (Liu et al., 2005), (Gaied et al., 2006), (Liu et al., 2006), (Dai et al., 2007), (Lee and Han, 2010), 52 (Martinez et al., 2010), (Avril et al., 2010) and (Dubuis et al., 2012).

53

However, some of the mechanisms by which MCS act(s) are still not clearly understood. The present study aims at addressing the effect of MCS on varicose veins by adopting a finite-element modelling approach. 


\section{Materials and methods}

\section{-1- Imaging methods}

Images are acquired on the calf of a 50 year old male patient with a varicose vein:

- Magnetic resonance imaging is applied with a two dimensional T1 TSE modality on a Siemens 1.5T scanner using (Opixel resolution: $0.7813 \times 0.7813 \mathrm{~mm} 2$, slice thickness: $3.9 \mathrm{~mm}())$.

- Echography is applied for obtaining images with a better spatial resolution in the region of the varicose vein. The ultrasound images are acquired with and without 15-20 mmHg MCS (AFNOR, 1986) both in the standing and supine position (Fig 1).

\section{-2- Finite Element Model}

Finite element mesh

The geometry is reconstructed from both MRI (deep tissues) and ultrasound scans (vein). The meshing tools available in $\mathrm{ABAQUS}{ }^{\circledR}$ are used to generate the computational mesh of the reconstructed geometry (Fig. 2). Continuum plane strain elements with a hybrid formulation are used for the muscle, fat and vein wall. A 2-D model is used since (Avril et al., 2010) showed that the 2-D approach predicts a similar pressure distribution in the calf tissues as a full 3-D model.

A hybrid formulation is preferred because the soft tissues are defined as quasi-incompressible (Poisson's ratio $>0.475$ ). Truss elements are used for the discretisation of the muscular aponeurosis, the skin and the MCS. A relatively finer discretisation is used around the vein. The models contain about 13600 elements and 33800 degrees of freedom (including the Lagrange multiplier variables). A mesh convergence study was conducted showing that further mesh refinement produces a negligible change in the solution.

\section{Internal blood pressure in the vein}

The intravascular pressure is accounted for by a constant pressure applied on the inner surface of the vein wall. The pressure imposed is $15 \mathrm{mmHg}$ in the supine position and $90 \mathrm{mmHg}$ in the standing position. This pressure is responsible for an initial pre-stress of the vein wall before applying compression, which is considered by applying an initial circumferential pre-stress on the vein wall to counterbalance this pressure. The value of the circumferential pre-stress in each element of the vein wall is determined by 
applying the Laplace law. A $1 \mathrm{kPa}$ pre-stress is also defined on the skin in the circumferential direction (Flynn et al., 2011).

\section{Boundary conditions}

The tibia and fibula are fixed in this model.

\section{Contact pressure on the skin.}

The interaction between the skin and the sock is enforced using the default ABAQUS ${ }^{\circledR}$ parameters in the normal direction (Tab. 1) and using a penalty method in the tangential direction. A skin-to-textile friction coefficient of 0.3 is used for the tangential direction, as reported in the literature (Gerhardt et al., 2009).

\section{Constitutive equations}

A summary is given in Tab 2. A linearized model is preferred for the vein because (i) the developed biomechanical model is used to simulate the deformation of the leg between two states of loading (compressed and uncompressed) which are very close one to the other, and (ii) we do not need to know the stress-free state of our leg as (it) is the case with nonlinear material behaviour models. The Poisson's ratio is fixed (to) at 0.49 (Wells and Liang, 2011) and two different stiffness values are identified, in supine and standing positions respectively, as the diameter reduction of the vein lumen, due to a $15-20 \mathrm{mmHg}$ class compression sock, is (of) $10 \%$ in the supine and (of) $3 \%$ in the standing position.

\section{Analysis procedure}

Simulation is divided into 3 steps as previously described:

Step 1 Initial stress on vein wall and skin and blood pressure loading

Step 2 Inflate sock and activate the contact conditions between the skin and the sock

Step 3 Release the MCS and calculate the equilibrium position

The resolution is performed via an implicit scheme. The default convergence criteria in ABAQUS/Standard are used (Tab. 1). 


\section{Results}

\section{-1- Mechanical properties of the vein wall and fat}

The FE model is calibrated against the echographic images of compressed and uncompressed legs acquired in the standing and supine positions. The identified Young's moduli for the vein wall are $100 \mathrm{kPa}$ in the supine position and $836 \mathrm{kPa}$ in the standing position. The identified $\mathrm{C}_{10}$ constant for the fat, characterizing the shear modulus in the Neo-Hookean strain energy function, is $5 \mathrm{kPa}$.

\section{-2- Parametric study}

Simulations are run corresponding to the supine and standing positions. Salient quantitative results of each simulation are reported in the Appendix through Table A1 to A7, where the influence of the following parameters is reported:

[a] Ratio of adipose tissue to leg size (Table A1);

[b] Position on the leg contour (Table A2);

[c] Vein lumen size (Table A3);

[d] Depth of vein in adipose tissue (Table A4);

[e] Effect of the applied external compression (Table A5);

[f] Influence of the "type" of fat (Table A6 for the influence of the stiffness and Table A7 for the influence of the incompressibility parameter).

Based on the results, it can be summarized that the biomechanical response of veins is subject to three main mechanical factors: the vein size, the local radius of curvature and the fat stiffness. This highlights the strong patient-specific response of the leg to external compression.

Parametric studies were also (run about) carried out on the element types, the type of contact and the type of material behaviour. Results (Tables A8 through A12) show that the modelling assumptions do not affect the trends (about) of the three main mechanical factors. 


\section{Discussion}

\section{-1- Material properties}

The stiffness properties of the fat and of the vessel wall are identified by Finite Element Model Updating. The obtained values are consistent with values reported in the literature. In a study to determine the in vitro elastic properties of human saphenous vein segments, (Wesly et al., 1975) reported that the in vitro saphenous tangent modulus in the circumferential direction is considerably smaller at pressure ranges corresponding to the supine position $(30 \mathrm{kPa}$ and $65 \mathrm{kPa}$ at $10 \mathrm{mmHg}$ and $25 \mathrm{mmHg}$ of pressure respectively) but is similar to carotid values at pressures similar to those encountered in vivo in the standing position (990 $\mathrm{kPa}$ and $1.5 \mathrm{MPa}$ at $75 \mathrm{mmHg}$ and $100 \mathrm{mmHg}$ of pressure respectively). This is consistent with other studies, conducted both in vivo and in vitro, showing that veins exhibit a non-linear mechanical behaviour and become stiffer as (it) they deform(s)(Buhs et al., 1999) (Zhao et al., 2007). More recently, based on the material parameters reported by (Chuong and Fung, 1986), Han estimated the Young's modulus of blood vessels to be $100 \mathrm{kPa}$ (Han, 2011). Material parameters of the Fung exponential strain energy function have also been reported for the human saphenous vein (Zhao et al., 2007) and for porcine jugular veins (Lee and Han, 2010). They are all comparable with the elastic properties found in our approach.

The material parameter identified for the fat lies within the range of values reported (by) in a study involving six patients. (Dubuis et al., 2012)

The fact that the narrowing of the vein is less pronounced in the standing position, for a given level of external compression, may also be due to the fact that the applied external pressure has to work against a higher internal blood pressure (Partsch and Partsch, 2005), (Partsch, 2007).

\section{-2- Main trends}

The results obtained using the proposed model show that hydrostatic pressure in fat is (i) (is) effectively increased and (ii) by an order of magnitude comparable to the mean contact pressure exerted by the MCS on the skin. 
170 The computed hydrostatic pressure in the fat is essential to understanding how the pressure is transmited

171 through the superficial soft tissues. Moreover the increase in tissue pressure is regarded as a crucial 172 mechanism (to the) in compressive treatments (Bergan, 2007). Clearly, appreciating how geometric and 173 material parameters affect the transmission of pressure is an important step to understanding both the 174 modes of action of EC treatment and the rationales behind its efficacy.

175

176 Other research teams have reported satisfactory results for the measurement of vein deformation under 177 compression (Partsch et al., 2010) but have not used these results for quantifying the trans-mural 178 pressures. The results of our model indicate that 15-20 mmHg MCS are effective in decreasing the trans179 mural pressure on vein walls. The values predicted are twice as high in the standing position than in the supine position. This trend corroborates that reported in vitro by (Gardon-Mollard and Ramel, 2008). 
From a clinical perspective, an increase of the trans-mural pressure on varicose vein walls exacerbates the disease and the underlying Chronic Venous Insufficiency (CVI). The goal of compression therapy is to restore a trans-mural pressure which is as normal as possible, by increasing the perivenous tissue pressure (Gardon-Mollard and Ramel, 2008). The results reported here confirm the idea that MCS work towards reducing the trans-mural pressure. In addition, trans-mural pressure is known to be related to the tension of the vein wall according to the Laplace law (Gusic et al., 2005). Reduction of the tension implies a smaller number of alterations in the vein wall associated with various pathologies. Another consequence is a greater stability with respect to axial buckling and tortuosity development (Han, 2007)(Han, 2009)(Han, 2012).

The action of MCS may also affect the remodelling of the vein. (Travers et al., 1996) (have) observed that varicose saphenous veins contained significantly higher amounts of collagen in all layers of the vein wall and that these collagen fibres were seen to invade and break up regular muscle layers of the media in varicosis. Reduction of the tension in the vein wall under the action of MCS is prone to hinder these effects. is both progressive and irreversible, clinical symptoms associated with venous insufficiency increase in severity with time (Suzuki et al., 2009). Important efforts are still necessary to predict numerically the long-term action of MCS in preventing the progression of venous stasis and the apparition of associated symptoms such as oedema, pigmentation, and ulcers on the skin. 


\section{Conclusion}

206

207

208

209

210

211

212

213

214

215

216

217

218

219

220

221

222 Conflict of interest

223 None clinical studies.

\section{Acknowledgement}

None
In this study, a FE model of a human leg with a varicose vein has been developed to compute the stress distribution in and around the vein wall and analyse the biomechanical response of varicose veins to external compression in terms of trans-mural pressures. Experimental data on the mechanical properties of healthy superficial veins and varicose veins being scarce in literature, ultrasound images of in vivo varicose veins have been acquired and analysed to extract the material constants of the vein wall and that of the fat, using Finite Element Model Updating.

The model (brings)provides a new insight on MCS mechanical action and its possible benefits. The results confirm the idea that MCS work towards reducing (the) trans-mural pressure and are effective in narrowing leg veins, which is important for the clinical consequences.

Future developments include a validation of the proposed approach and of its medical outcomes using

224 
AFNOR, 1986. NF G30-102. Article de bonneterie - Détermination de la pression de contention.

227

228

Agu, O., Hamilton, G., Baker, D., 1999. Graduated compression stockings in the prevention of venous thromboembolism. British Journal of Surgery 86, 992-1004.

Avril, S., Bouten, L., Dubuis, L., Drapier, S., Pouget, J.-F., 2010. Mixed Experimental and Numerical Approach for Characterizing the Biomechanical Response of the Human Leg Under Elastic Compression. Journal of Biomechanical Engineering 132, 31006-31014.

Bergan, J.J., 2007. The Vein Book. Academic Press.

Best, A.J., Williams, S., Crozier, A., Bhatt, R., Gregg, P.J., Hui, A.C.W., 2000. Graded compression stockings in elective orthopaedic surgery. J Bone Joint Surg Br 82-B, 116-118.

Buhs, C.L., Bendick, P.J., Glover, J.L., 1999. The effect of graded compression elastic stockings on the lower leg venous system during daily activity. Journal of Vascular Surgery 30, 830-835.

Chuong, C.J., Fung, Y.C., 1986. On Residual Stresses in Arteries. Journal of Biomechanical Engineering 108, 189-192.

Dai, X., Liu, R., Li, Y., Zhang, M., Kwok, Y., 2007. Computational Textile, in: Studies in Computational Intelligence. Springer Berlin / Heidelberg, pp. 301-309.

Downie, S.P., Raynor, S.M., Firmin, D.N., Wood, N.B., Thom, S.A., Hughes, A.D., Parker, K.H., Wolfe, J.H.N., Xu, X.Y., 2008. Effects of Elastic Compression Stockings on Wall Shear Stress in Deep and Superficial Veins of the Calf. Am J Physiol Heart Circ Physiol 294, H2112-H2120.

Dubuis, L., Avril, S., Debayle, J., Badel, P., 2012. Identification of the material parameters of soft tissues in the compressed leg. Computer Methods in Biomechanics and Biomedical Engineering 15, 3-11.

Flynn, C., Taberner, A., Nielsen, P., 2011. Mechanical characterisation of in vivo human skin using a 3D force-sensitive micro-robot and finite element analysis. Biomechanics and Modeling in Mechanobiology $10,27-38$.

Gaied, I., Drapier, S., Lun, B., 2006. Experimental assessment and analytical 2D predictions of the stocking pressures induced on a model leg by Medical Compressive Stockings. Journal of Biomechanics 39, 30173025.

Gardon-Mollard, Ramel, 2008. La compression médicale. Elsevier Masson.

Gerhardt, L. -c, Lenz, A., Spencer, N.D., Münzer, T., Derler, S., 2009. Skin-textile friction and skin elasticity in young and aged persons. Skin Research and Technology 15, 288-298.

Guesdon, P., Fullana, J.-M., Flaud, P., 2007. Experimental study of muscular draining. Comptes Rendus Mécanique 335, 207-212.

Gusic, R.J., Petko, M., Myung, R., William Gaynor, J., Gooch, K.J., 2005. Mechanical properties of native and ex vivo remodeled porcine saphenous veins. Journal of Biomechanics 38, 1770-1779.

Hamel-Desnos, C.M., Guias, B.J., Desnos, P.R., Mesgard, A., 2010. Foam Sclerotherapy of the Saphenous Veins: Randomised Controlled Trial with or without Compression. European Journal of Vascular and Endovascular Surgery 39, 500-507. 
Han, H.-C., 2009. Blood vessel buckling within soft surrounding tissue generates tortuosity. Journal of Biomechanics 42, 2797-2801.

Han, H.-C., 2011. Determination of the Critical Buckling Pressure of Blood Vessels Using the Energy Approach. Ann Biomed Eng 39, 1032-1040.

Ibegbuna, V., Delis, K.T., Nicolaides, A.N., Aina, O., 2003. Effect of elastic compression stockings on venous hemodynamics during walking. Journal of Vascular Surgery 37, 420-425.

Kamm, R.D., Shapiro, A.H., 1979. Unsteady Flow in a Collapsible Tube Subjected to External Pressure or Body Forces. Journal of Fluid Mechanics 95, 1-78.

Katz, A.I., Chen, Y., Moreno, A.H., 1969. Flow through a Collapsible Tube: Experimental Analysis and Mathematical Model. Biophysical Journal 9, 1261-1279.

Kern, P., Ramelet, A.-A., Wütschert, R., Hayoz, D., 2007. Compression after sclerotherapy for telangiectasias and reticular leg veins: A randomized controlled study. Journal of Vascular Surgery 45, 1212-1216.

Lee, A., Han, H.-C., 2010. A Nonlinear Thin-Wall Model for Vein Buckling. Cardiovascular Engineering and Technology 1, 282-289.

Liu, R., Kwok, Y.-L., Li, Y., Lao, T.-T., Zhang, X., Dai, X., 2006. A three-dimensional biomechanical model for numerical simulation of dynamic pressure functional performances of graduated compression stocking (GCS). Fibers and Polymers 7, 389-397.

Liu, R., Kwok, Y.L., Li, Y., Lao, T.T.H., Zhang, X., Dai, X.Q., 2005. Objective Evaluation of Skin Pressure Distribution of Graduated Elastic Compression Stockings. Dermatologic Surgery 31, 615-624.

Martinez, R., Fierro, C., Shireman, P., Han, H.-C., 2010. Mechanical Buckling of Veins Under Internal Pressure. Annals of Biomedical Engineering 38, 1345-1353.

Mayberry, J.C., Moneta, G.L., De Frang, R.D., Porter, J.M., 1991. The influence of elastic compression stockings on deep venous hemodynamics. Journal of Vascular Surgery 13, 91-100.

Moreno, A.H., Katz, A.I., Gold, L.D., Reddy, R.V., 1970. Mechanics of Distension of Dog Veins and Other Very Thin-Walled Tubular Structures. Circulation Research 27, 1069-1080.

Nehler, M.R., Moneta, G.L., Chitwood, R.W., Porter, J.M., 1992. The Lower Extremity Venous System Part III: Nonoperative Treatment of Chronic Venous Insufficiency. PERSPECT VASC SURG ENDOVASC THER 5, $100-114$.

Nehler, M.R., Moneta, G.L., Woodard, D.M., Defrang, R.D., Harker, C.T., Taylor Jr., L.M., Porter, J.M., 1993. Perimalleolar subcutaneous tissue pressure effects of elastic compression stockings. Journal of Vascular Surgery 18, 783-788.

Partsch, B., Partsch, H., 2005. Calf compression pressure required to achieve venous closure from supine to standing positions. Journal of Vascular Surgery 42, 734-738.

Partsch, H., 2007. Chapter 10 - Mechanism and effects of compression therapy, in: The Vein Book. Academic Press, Burlington, pp. 103-109.

Partsch, H., Mosti, G., Mosti, F., 2010. Narrowing of leg veins under compression demonstrated by magnetic resonance imaging (MRI). Int Angiol 29, 408-410. 

Impaired lymphatic function recovered after great saphenous vein stripping in patients with varicose vein: Venodynamic and lymphodynamic results. Journal of Vascular Surgery 50, 1085-1091.

Travers, J.P., Brookes, C.E., Evans, J., Baker, D.M., Kent, C., Makin, G.S., Mayhew, T.M., 1996. Assessment of wall structure and composition of varicose veins with reference to collagen, elastin and smooth muscle content. European Journal of Vascular and Endovascular Surgery 11, 230-237.

Villavicencio, J., 2009. Sclerotherapy in the management of varicose veins of the extremities., in: Handbook of Venous Disorders: Guidelines of the American Venous Forum. Gloviczki, P. and Yao J., London, pp. 366379.

Wang, Y., Pierce, I., Gatehouse, P., Wood, N., Firmin, D., Xu, X.Y., 2012. Analysis of flow and wall shear stress in the peroneal veins under external compression based on real-time MR images. Medical Engineering \& Physics 34, 17-27.

Wells, P.N.T., Liang, H.-D., 2011. Medical Ultrasound: Imaging of Soft Tissue Strain and Elasticity. J. R. Soc. Interface 8, 1521-1549.

Wesly, R.L., Vaishnav, R.N., Fuchs, J.C., Patel, D.J., Greenfield, J.C., 1975. Static Linear and Nonlinear Elastic

315 Properties of Normal and Arterialized Venous Tissue in Dog and Man. Circulation Research 37, 509-520.

Wildin, C.J., Hui, A.C.W., Esler, C.N.A., Gregg, P.J., 1998. In vivo pressure profiles of thigh-length graduated compression stockings. British Journal of Surgery 85, 1228-1231.

318 Yeung, K.W., Li, Y., Zhang, X., 2004. A 3D Biomechanical Human Model for Numerical Simulation of 319 Garment-Body Dynamic Mechanical Interactions During Wear. Journal of the Textile Institute 95, 59-79.

320 Zhao, J., Jesper Andreasen, J., Yang, J., Steen Rasmussen, B., Liao, D., Gregersen, H., 2007. Manual pressure 321 distension of the human saphenous vein changes its biomechanical properties-implication for coronary artery bypass grafting. Journal of Biomechanics 40, 2268-2276. 


\section{List of figures}

\begin{tabular}{|l|l|}
\hline Figure 1 & $\begin{array}{l}\text { Acquisition of Echographic images both in the standing and supine position (1a and } \\
\text { 1b). A special precaution was taken as illustrated in figure 1c. }\end{array}$ \\
\hline Figure 2 & $\begin{array}{l}\text { Finite element mesh of the 2D patient specific mesh. It consists of continuum plane } \\
\text { strain elements for the muscle, fat and vein wall and truss elements for the muscular } \\
\text { aponeurosis, skin and MCS. A relatively finer discretisation is used in the vicinity of } \\
\text { the vein wall. The thickness-to-radius ratio of the vein is taken as 0.1, as reported in } \\
\text { the literature. }\end{array}$
\end{tabular}

\section{List of tables}

\begin{tabular}{|l|l|}
\hline Table 1 & Material properties of the different constitutive parts of the model \\
\hline Table 2 & Default ABAQUS parameters used for the simulation (Hibbitt, 2009) \\
\hline
\end{tabular}




\begin{tabular}{|c|c|}
\hline Table A1 & $\begin{array}{l}\text { Influence of the ratio of adipose tissue to leg size. The thickness of the adipose tissue } \\
\text { has been modified during the segmentation step to account for different } \\
\text { morphologies of subcutaneous adipose tissue (Reference configuration and } \\
\text { geometries } 1,2 \text { and } 3 \text { hereunder). The results show that the amount of adipose } \\
\text { tissue has a negligible influence both on the decrease in the vein cross-section and on } \\
\text { the decrease in trans-mural pressure. }\end{array}$ \\
\hline Table A2 & $\begin{array}{l}\text { Influence of the position of the vein on the leg contour. The vein is placed at different } \\
\text { positions on the leg contour (Reference configuration and geometries } 1,2 \text { and } 3 \\
\text { hereunder). The maximum values of decrease in trans-mural pressure, percentage } \\
\text { circumferential stretch ratio and increase in hydrostatic pressure in fat, are obtained } \\
\text { when the radius of curvature is the smallest. These results confirm that the } \\
\text { performance of the MCS is correlated to the local radius of curvature of the leg. }\end{array}$ \\
\hline Table A3 & $\begin{array}{l}\text { Influence of the cross-sectional area of the vein. Different veins are generated from } \\
\text { the segmented geometry of the vein in vivo by doing a dilation of the semi-minor and } \\
\text { semi-major axes respectively. The centre of dilation is taken as the centre of the vein } \\
\text { and the scaling factor as } 0.7,0.5 \text { and } 0.2 \text { respectively (Reference configuration and } \\
\text { geometries } 1,2 \text { and } 3 \text { hereunder). The results show that MCS have a slightly more } \\
\text { important effect as the cross section decreases, but overall the numerical values are } \\
\text { very close. A more pronounced effect is obtained in the supine position. }\end{array}$ \\
\hline Table A4 & $\begin{array}{l}\text { Influence of the depth of the vein in the adipose tissue. New geometries are obtained } \\
\text { by translating the vein in the direction of the skin or, on the contrary, closer to the } \\
\text { muscular aponeurosis (Reference configuration and geometries } 1,2 \text { and } 3 \\
\text { hereunder). Almost no effect is obtained in the supine position. In the standing } \\
\text { position, however, the benefit on the decrease in trans-mural pressure due to } \\
\text { external compression, slightly but steadily increases (as) when the vein is closer to } \\
\text { the skin. }\end{array}$ \\
\hline Table A5 & $\begin{array}{l}\text { Influence of the external compression applied. The stiffness of the sock used in the } \\
\text { reference model is multiplied by a constant of proportionality (i.e. } 1,2 \text { and } 3 \text { ). The } \\
\text { mean contact pressure delivered for each case is reported below. Results show a fine } \\
\text { linear relationship between the mean contact pressure and the response of the leg. } \\
\text { We observe moreover that the response is different in the standing and supine } \\
\text { position, except for the mean increase in hydrostatic pressure in fat. }\end{array}$ \\
\hline Table A6 & $\begin{array}{l}\text { Influence of the stiffness of the fat. Different "types" of fat are modelled by changing } \\
\mathrm{C}_{10} \text {. The values are taken in the range } 3-8 \mathrm{kPa} \mathrm{C}_{10} \text {. Results are reported hereunder. } \\
\text { The main result is the significant influence of this parameter on the percentage } \\
\text { compression of the vein in the supine position and the quasi-insignificant influence } \\
\text { in the standing position. }\end{array}$ \\
\hline Table A7 & $\begin{array}{l}\text { Influence of the compressibility of the fat. Different "types" of fat are modelled by } \\
\text { changing } \mathrm{D}_{1} \text {. The values are taken in the range } 0.005-10 \mathrm{MPa}^{-1} \text {. Results are reported } \\
\text { hereunder. Almost no effect is obtained either in the supine or standing positions. }\end{array}$ \\
\hline Table A8 & $\begin{array}{l}\text { Influence of the constitutive behaviour law used to model the vein wall. Two types of } \\
\text { behaviour laws were compared (i) bi-linear elastic and (ii) Neo-Hookean } \\
\text { hyperelastic material model. Only weak differences are observed in the results. }\end{array}$ \\
\hline Table A9 & $\begin{array}{l}\text { Influence of the element type used for the Finite Element mesh. Three aspects were } \\
\text { considered (i) hybrid formulation of the elements (ii) reduced integration of these } \\
\text { and (iii) geometric order (linear/quadratic). Results show that the choice of element } \\
\text { formulation does not affect key conclusions of the study derived from the modelling }\end{array}$ \\
\hline
\end{tabular}




\begin{tabular}{|l|l|}
\hline & results. \\
\hline Table A10 & $\begin{array}{l}\text { Influence of the contact formulation for the Fat/Vein interface (Fat/Vein). Two } \\
\text { aspects of the contact specifications were considered: (i) normal and (ii) tangential } \\
\text { behaviour of the contact interaction properties. Both "hard" and "soft" constraint } \\
\text { methods were investigated for enforcing the contact pressure-overclosure } \\
\text { relationship (normal direction). Furthermore, a tie constraint (each node on the } \\
\text { slave surface is constrained to have the same motion as the point on the master } \\
\text { surface to which it is closest) was also investigated in place of the contact interaction. } \\
\text { Results show minor changes. }\end{array}$ \\
\hline Table A11 & $\begin{array}{l}\text { Influence of the contact formulation for the Fat/Muscle interface (Fat/Muscle). The } \\
\text { same contact conditions were investigated. Very little change was observed. }\end{array}$ \\
\hline Table A12 & $\begin{array}{l}\text { Influence of the contact formulation for the Skin/MCS interface (Skin/MCS). Results } \\
\text { show that the "softened" contact algorithms available in ABAQUS/Standard (and } \\
\text { subsequently retained as a constraint method for enforcing the contact pressure- } \\
\text { overclosure relationship) performed better than the "hard" contact algorithms. The } \\
\text { main advantage of the "softened" contact algorithms is that clearance is calculated } \\
\text { from surface to surface instead of from node to surface. As a consequence, the } \\
\text { contact load is evenly distributed along the interacting surfaces. }\end{array}$ \\
\hline
\end{tabular}

332 


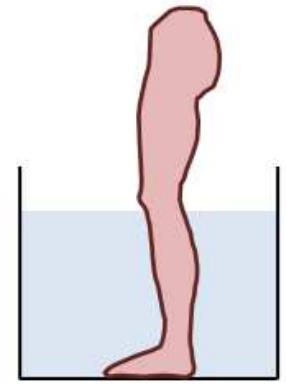

(a)

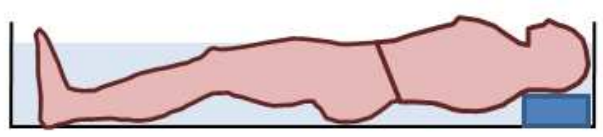

(b)

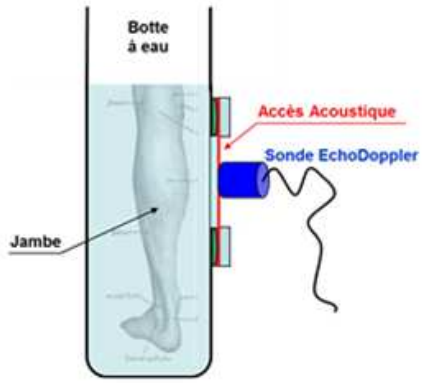

(c)

Figure 1. Acquisition of echographic images both in the standing and supine position (a and b). A special precaution was taken as illustrated in panel c. 


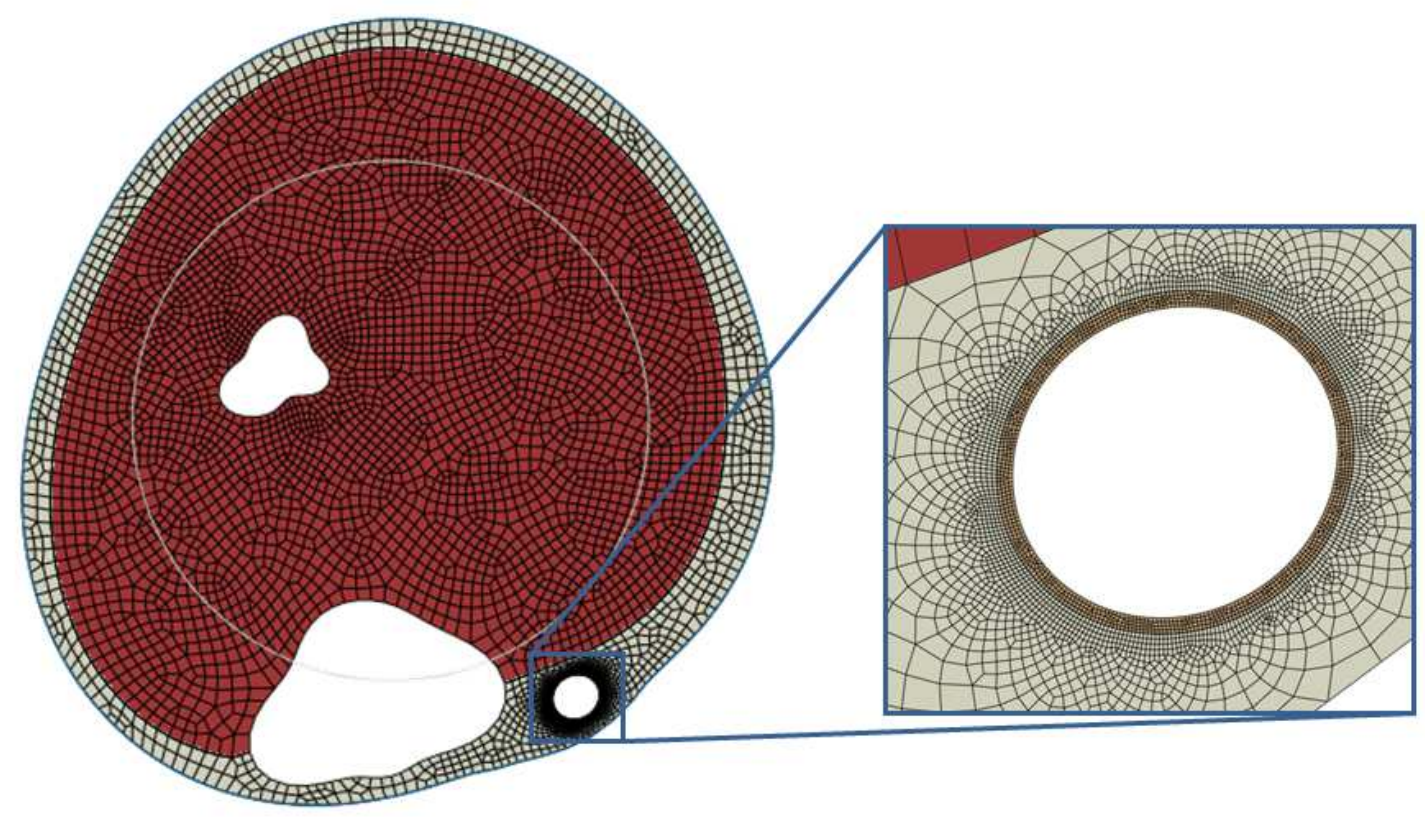

Figure 2: Finite element mesh of the 2D patient specific mesh. It consists of continuum plane strain elements for the muscle, fat and vein wall and truss elements for the muscular aponeurosis, skin and MCS. A relatively finer discretisation is used in the vicinity of the vein wall. The thickness-to-radius ratio of the vein is taken as 0.1, as reported in the literature. 


\begin{tabular}{|c|c|}
\hline Simulation element & ABAQUS parameters used \\
\hline Truss elements & Truss cross-sectional area $=1.0 \mathrm{~mm}^{2}$ \\
\hline $\begin{array}{l}\text { Contact pairs (for } \\
\text { surfaces in contact) }\end{array}$ & Contact algorithm: pure master-slave contact \\
\hline $\begin{array}{l}\text { Contact between } \\
\text { Skin and textile }\end{array}$ & $\begin{array}{l}\text { Tangential Behaviour: } \\
\text { Friction formulation=PENALTY, } \\
\text { Behaviour independent of slip rate, pressure and temperature, } \\
\text { friction coefficient = } 0.3 \\
\text { Normal Behaviour : } \\
\text { Contact pressure-overclosure relationship= EXPONENTIAL (SOFT), } \\
\text { This means that the contact pressure transmitted between the two } \\
\text { interacting surfaces increases exponentially as the clearance between them, } \\
\text { measured in the contact (normal) direction, diminishes (starting from a user- } \\
\text { defined threshold value). } \\
\text { Separation of the surfaces is not allowed } \\
\text { Constraint Enforcement Method= PENALTY }\end{array}$ \\
\hline Contact fat-muscle & $\begin{array}{l}\text { Tangential Behaviour : FRICTIONLESS } \\
\text { Normal Behaviour: } \\
\text { Contact pressure-overclosure relationship= EXPONENTIAL } \\
\text { Separation of the surfaces is not allowed } \\
\text { Constraint enforcement method= AUGMENTED_LAGRANGE }\end{array}$ \\
\hline $\begin{array}{l}\text { Constraint between } \\
\text { surfaces :- } \\
-1-\text { Bone-Fat } \\
\text {-2- Bone-Muscle } \\
\text {-3- Fat-Vein } \\
-4-\text { Aponeurosis-Muscle } \\
\text {-5- Skin-Fat }\end{array}$ & $\begin{array}{l}\text { Type of constraint: TIE } \\
\text { Tie constraint means that each node on the slave surface is constrained to } \\
\text { have the same motion as the point on the master surface to which it is closest } \\
\text { Slave surfaces are adjusted so that surfaces are in contact } \\
\text { Rotational DOF are also tied }\end{array}$ \\
\hline $\begin{array}{l}\text { Steps of the FE analysis } \\
\text { (steps } 1 \text { to } 3 \text { ) }\end{array}$ & $\begin{array}{l}\text { Implicit resolution } \\
\text { Maximum number of steps allowed }=100 \\
\text { Initial increment time step size }=1.0 \mathrm{~s} \\
\text { Minimum increment time step size }=1 \mathrm{e}-5 \mathrm{~s} \\
\text { Maximum increment time step size }=1.0 \mathrm{~s} \\
\text { Nlgeom=0N } \\
\text { Solution technique = Full Newton } \\
\text { Equation solver = Direct (i.e. the solver finds the exact solution (up to } \\
\text { machine precision) of the set of linear equations obtained at each iteration of } \\
\text { the Newton method. It uses a sparse, direct, Gauss elimination method) }\end{array}$ \\
\hline
\end{tabular}

Table 1: Default ABAQUS parameters used for the simulation (Hibbitt, 2009). 


\begin{tabular}{|c|c|c|c|}
\hline Material & Model & Material parameters & Source \\
\hline Fat & $\begin{array}{l}\text { Hyper-elastic } \\
\text { Neo-Hookean }\end{array}$ & $\begin{array}{l}\mathrm{C}_{10}=0.005 \mathrm{MPa} \\
\mathrm{D}_{1}=0.14 \mathrm{MPa}^{-1}\end{array}$ & $\begin{array}{c}\text { Inverse identification } \\
\text { (Dubuis et al., 2011) } \\
\text { (Avril et al., 2010) } \\
\end{array}$ \\
\hline Muscle & $\begin{array}{l}\text { Hyper-elastic } \\
\text { Neo-Hookean }\end{array}$ & $\begin{array}{l}\mathrm{C}_{10}=0.003 \mathrm{MPa} \\
\mathrm{D}_{1}=0.14 \mathrm{MPa}^{-1}\end{array}$ & $\begin{array}{c}\text { (Dubuis et al., 2011) } \\
\text { (Avril et al., 2010) }\end{array}$ \\
\hline Skin & $\begin{array}{l}\text { Hyper-elastic } \\
\text { Neo-Hookean }\end{array}$ & $\begin{array}{c}\mathrm{C}_{10}=0.1 \mathrm{MPa} \\
\mathrm{D}_{1}=0.14 \mathrm{MPa}^{-1}\end{array}$ & $\begin{array}{l}\text { (Iivarinen et al., 2011) } \\
\text { (Hendriks et al., 2006) }\end{array}$ \\
\hline $\begin{array}{c}\text { Muscular } \\
\text { aponeurosis }\end{array}$ & $\begin{array}{l}\text { Hyper-elastic } \\
\text { Neo-Hookean }\end{array}$ & $\begin{array}{c}\mathrm{C}_{10}=10 \mathrm{MPa} \\
\mathrm{D}_{1}=80 \mathrm{MPa}^{-1}\end{array}$ & $(\mathrm{Wu}, 2007)$ \\
\hline Vein wall & $\begin{array}{l}\text { Linearized (in } \\
\text { standing and } \\
\text { resting positions } \\
\text { respectively) }\end{array}$ & $v=0.49$ (fixed) & Inverse identification \\
\hline MCS & Linear elastic & $\begin{array}{l}E=0.39 \\
v=0.49\end{array}$ & $\begin{array}{c}\text { SIGVARIS tensile test on 15- } \\
20 \text { mmHg MCS and based } \\
\text { on the French norm NF- } \\
\text { G30-102 (AFNOR, 1986) }\end{array}$ \\
\hline
\end{tabular}

Table 2: Material properties of the different constitutive parts of the model. 


\begin{tabular}{|c|c|c|c|c|c|c|c|c|c|c|c|c|c|c|c|c|}
\hline \multicolumn{17}{|l|}{ Morphology of adipose tissue } \\
\hline \multirow{2}{*}{$\begin{array}{l}\text { Note : all pressures given in } \\
\mathrm{mmHg}\end{array}$} & \multicolumn{4}{|c|}{ Reference configuration } & \multicolumn{4}{|c|}{ Geometry1 } & \multicolumn{4}{|c|}{ Geometry2 } & \multicolumn{4}{|c|}{ Geometry3 } \\
\hline & Supine & & Standing & & Supine & & Standing & & Supine & & Standin & & Supine & & Standing & \\
\hline $\begin{array}{l}\text { Percentage circumferential } \\
\text { reduction of the vein lumen }\end{array}$ & 10.0 & & 3.2 & & 10.1 & & 3.3 & & 10.2 & & 3.3 & & 10.3 & & 3.3 & \\
\hline $\begin{array}{l}\text { Average contact pressure at } \\
\text { skin-sock interface }\end{array}$ & 17.3 & \pm 5.3 & 17.4 & \pm 5.8 & 17.3 & \pm 5.4 & 17.3 & \pm 6.0 & 17.4 & \pm 5.8 & 17.4 & \pm 6.1 & 17.4 & \pm 5.5 & 17.4 & \pm 6.0 \\
\hline $\begin{array}{l}\text { Mean trans-mural pressure in } \\
\text { vein wall before EC }\end{array}$ & 11.0 & \pm 1.1 & 67.2 & \pm 5.4 & 11.0 & \pm 1.1 & 67.1 & \pm 5.5 & 11.0 & \pm 1.1 & 67.1 & \pm 5.7 & 11.0 & \pm 1.1 & 67.1 & \pm 6.0 \\
\hline $\begin{array}{l}\text { Mean decrease of trans-mural } \\
\text { pressure in vein wall due to } \\
\text { EC }\end{array}$ & 4.8 & \pm 2.5 & 12.3 & \pm 11.1 & 4.8 & \pm 2.7 & 12.2 & \pm 11.7 & 5.0 & \pm 2.5 & 12.6 & \pm 11.0 & 4.9 & \pm 2.6 & 12.5 & \pm 11.3 \\
\hline $\begin{array}{l}\text { Mean increase in hydrostatic } \\
\text { pressure in fat due to EC }\end{array}$ & 19.8 & \pm 3.7 & 19.9 & \pm 6.6 & 19.7 & \pm 3.7 & 19.5 & \pm 6.4 & 19.6 & \pm 3.6 & 19.8 & \pm 5.8 & 19.2 & \pm 3.5 & 19.5 & \pm 5.7 \\
\hline $\begin{array}{l}\text { Maximum hydrostatic } \\
\text { pressure in fat }\end{array}$ & 29.0 & & 39.3 & & 32.8 & & 44.0 & & 41.2 & & 43.8 & & 29.9 & & 39.3 & \\
\hline
\end{tabular}

Note: average results given as mean \pm standard deviation

Table A1: Ratio of adipose tissue to leg size 


\begin{tabular}{|c|c|c|c|c|c|c|c|c|c|c|c|c|c|c|c|c|}
\hline \multicolumn{17}{|l|}{$\begin{array}{l}\text { Position of the vein on the leg } \\
\text { contour }\end{array}$} \\
\hline \multirow{2}{*}{$\begin{array}{l}\text { Note : all pressures given in } \\
\mathrm{mmHg}\end{array}$} & \multicolumn{4}{|c|}{ Reference configuration } & \multicolumn{4}{|c|}{ Geometry1 } & \multicolumn{4}{|c|}{ Geometry2 } & \multicolumn{4}{|c|}{ Geometry3 } \\
\hline & Supine & & Standing & & Supine & & Standing & & Supine & & Standin & & Supine & & Standin & \\
\hline $\begin{array}{l}\text { Percentage circumferential } \\
\text { reduction of the vein lumen }\end{array}$ & 10.0 & & 3.2 & & 11.0 & & 3.5 & & 12.3 & & 4.0 & & 10.7 & & 4.0 & \\
\hline $\begin{array}{l}\text { Average contact pressure at } \\
\text { skin-sock interface }\end{array}$ & 17.3 & \pm 5.3 & 17.4 & \pm 5.8 & 17.3 & \pm 5.4 & 17.3 & \pm 6.0 & 17.4 & \pm 5.8 & 17.4 & \pm 6.1 & 17.5 & \pm 5.5 & 17.4 & \pm 6.1 \\
\hline $\begin{array}{l}\text { Mean trans-mural pressure in } \\
\text { vein wall before EC }\end{array}$ & 11.0 & \pm 1.1 & 67.2 & \pm 5.4 & 11.0 & \pm 1.1 & 67.1 & \pm 5.4 & 11.0 & \pm 1.1 & 67.2 & \pm 5.6 & 11.0 & \pm 1.1 & 67.2 & \pm 5.6 \\
\hline $\begin{array}{l}\text { Mean decrease of trans-mural } \\
\text { pressure in vein wall due to } \\
\text { EC }\end{array}$ & 4.8 & \pm 2.5 & 12.3 & \pm 11.1 & 5.3 & \pm 2.1 & 13.2 & \pm 11.2 & 6.0 & \pm 3.5 & 14.9 & \pm 12.0 & 5.1 & \pm 2.9 & 14.9 & \pm 12.0 \\
\hline $\begin{array}{l}\text { Mean increase in hydrostatic } \\
\text { pressure in fat due to EC }\end{array}$ & 19.8 & \pm 3.7 & 19.9 & \pm 6.6 & 21.4 & \pm 4.8 & 20.6 & \pm 7.0 & 23.1 & \pm 5.9 & 22.2 & \pm 7.1 & 21.1 & \pm 4.7 & 22.2 & \pm 7.1 \\
\hline $\begin{array}{l}\text { Maximum hydrostatic } \\
\text { pressure in fat }\end{array}$ & 29.0 & & 39.3 & & 48.0 & & 48.0 & & 42.9 & & 54.9 & & 42.7 & & 54.9 & \\
\hline
\end{tabular}

Note: average results given as mean \pm standard deviation

Table A2: Position on the leg contour 


\begin{tabular}{|c|c|c|c|c|c|c|c|c|c|c|c|c|c|c|c|c|}
\hline $\begin{array}{l}\text { Initial vein } \mathrm{c} / \mathrm{s} \text { of vein lumen } \\
\text { (in } \mathrm{mm} 2 \text { ) }\end{array}$ & 21.9 & & & & 11.2 & & & & 5.9 & & & & 1.0 & & & \\
\hline \multirow{2}{*}{$\begin{array}{l}\text { Note : all pressures given in } \\
\mathrm{mmHg}\end{array}$} & \multicolumn{4}{|c|}{ Reference configuration } & \multicolumn{4}{|c|}{ Geometry1 } & \multicolumn{4}{|c|}{ Geometry2 } & \multicolumn{4}{|c|}{ Geometry3 } \\
\hline & Supine & & Standing & & Supine & & Standing & & Supine & & Standing & & Supine & & Standing & \\
\hline reduction of the vein lumen & 10.0 & & 3.2 & & 10.3 & & 3.4 & & 10.4 & & 3.5 & & 10.6 & & 3.6 & \\
\hline $\begin{array}{l}\text { Average contact pressure at } \\
\text { skin-sock interface }\end{array}$ & 17.3 & \pm 5.3 & 17.4 & \pm 5.8 & 17.3 & \pm 5.5 & 17.4 & \pm 5.7 & 17.3 & \pm 5.6 & 17.3 & \pm 5.8 & 17.3 & \pm 5.7 & 17.3 & \pm 5.7 \\
\hline $\begin{array}{l}\text { Mean trans-mural pressure in } \\
\text { vein wall before EC }\end{array}$ & 11.0 & \pm 1.1 & 67.2 & \pm 5.4 & 8.8 & \pm 0.7 & 63.5 & \pm 4.6 & 7.5 & \pm 0.6 & 61.2 & \pm 4.3 & 5.5 & \pm 0.4 & 57.6 & \pm 4.1 \\
\hline $\begin{array}{l}\text { Mean decrease of trans-mural } \\
\text { pressure in vein wall due to } \\
\text { EC }\end{array}$ & 4.8 & \pm 2.5 & 12.3 & \pm 11.1 & 5.3 & \pm 2.3 & 12.4 & \pm 9.7 & 5.6 & \pm 2.3 & 12.4 & \pm 8.9 & 5.9 & \pm 2.6 & 12.4 & \pm 8.5 \\
\hline $\begin{array}{l}\text { Mean increase in hydrostatic } \\
\text { pressure in fat due to EC }\end{array}$ & 19.8 & \pm 3.7 & 19.9 & \pm 6.6 & 20.5 & \pm 3.7 & 20.5 & \pm 5.6 & 20.6 & \pm 3.8 & 20.9 & \pm 5.2 & 20.8 & \pm 3.5 & 21.1 & \pm 4.0 \\
\hline $\begin{array}{l}\text { Maximum hydrostatic } \\
\text { pressure in fat }\end{array}$ & 29.0 & & 39.3 & & 29.7 & & 36.3 & & 33.4 & & 36.2 & & 33.6 & & 34.1 & \\
\hline
\end{tabular}

Note: average results given as mean \pm standard deviation

Table A3: Vein lumen size 


\begin{tabular}{|c|c|c|c|c|c|c|c|c|c|c|c|c|c|c|c|c|}
\hline Distance to skin (mm) & \multirow{2}{*}{\multicolumn{4}{|c|}{ Geometry1 }} & \multicolumn{4}{|c|}{1.96} & \multicolumn{4}{|l|}{1.33} & \multicolumn{4}{|l|}{0.39} \\
\hline \multirow{2}{*}{$\begin{array}{l}\text { Note : all pressures given in } \\
\text { mmHg }\end{array}$} & & & & & Referen & e confi & uration & & Geomet & & & & Geometı & & & \\
\hline & \multicolumn{2}{|l|}{ Supine } & \multicolumn{2}{|c|}{ Standing } & Supine & & \multicolumn{2}{|c|}{ Standing } & \multicolumn{2}{|l|}{ Supine } & \multicolumn{2}{|c|}{ Standing } & Supine & & \multicolumn{2}{|c|}{ Standing } \\
\hline reduction of the vein lumen & 10.2 & & 3.1 & & 10.0 & & 3.2 & & 10.2 & & 3.4 & & 10.2 & & 3.5 & \\
\hline $\begin{array}{l}\text { Average contact pressure at } \\
\text { skin-sock interface }\end{array}$ & 17.3 & \pm 5.6 & 17.3 & \pm 6.1 & 17.3 & \pm 5.3 & 17.4 & \pm 5.8 & 17.3 & \pm 5.3 & 17.3 & \pm 5.8 & 17.3 & \pm 5.4 & 17.3 & \pm 5.9 \\
\hline $\begin{array}{l}\text { Mean trans-mural pressure in } \\
\text { vein wall before EC }\end{array}$ & 11.0 & \pm 1.2 & 67.4 & \pm 5.7 & 11.0 & \pm 1.1 & 67.2 & \pm 5.4 & 11.0 & \pm 1.1 & 67.2 & \pm 5.6 & 11.0 & \pm 1.1 & 67.2 & \pm 5.5 \\
\hline $\begin{array}{l}\text { Mean decrease of trans-mural } \\
\text { pressure in vein wall due to } \\
\text { EC }\end{array}$ & 4.8 & \pm 2.9 & 11.9 & \pm 11.6 & 4.8 & \pm 2.5 & 12.3 & \pm 11.1 & 4.9 & \pm 2.5 & 12.8 & \pm 11.5 & 4.9 & \pm 3.3 & 13.4 & \pm 12.5 \\
\hline $\begin{array}{l}\text { Mean increase in hydrostatic } \\
\text { pressure in fat due to EC }\end{array}$ & 20.2 & \pm 3.8 & 19.7 & \pm 7.0 & 19.8 & \pm 3.7 & 19.9 & \pm 6.6 & 19.7 & \pm 3.7 & 19.8 & \pm 6.3 & 19.4 & \pm 4.0 & 19.9 & \pm 6.5 \\
\hline $\begin{array}{l}\text { Maximum hydrostatic } \\
\text { pressure in fat }\end{array}$ & 32.9 & & 44.4 & & 29.0 & & 39.3 & & 29.4 & & 41.8 & & 32.7 & & 66.2 & \\
\hline
\end{tabular}

Note: average results given as mean \pm standard deviation

Table A4: Depth of vein in adipose tissue 


\begin{tabular}{|c|c|c|c|c|c|c|c|c|c|c|c|c|c|c|c|c|}
\hline $\begin{array}{l}\text { Mean external compression } \\
\text { applied on skin (mmHg) }\end{array}$ & \multicolumn{4}{|l|}{17.4} & \multicolumn{4}{|l|}{34.7} & \multicolumn{4}{|l|}{52.0} & \multicolumn{4}{|l|}{69.4} \\
\hline \multirow{2}{*}{$\begin{array}{l}\text { Note : all pressures given in } \\
\text { mmHg }\end{array}$} & \multicolumn{4}{|c|}{ Reference configuration } & \multicolumn{4}{|c|}{ Configuration 1} & \multicolumn{4}{|c|}{ Configuration 2} & \multicolumn{4}{|c|}{ Configuration 3} \\
\hline & Supine & & Standin & & Supine & & Standing & & Supine & & Standin & & Supine & & Standing & \\
\hline reduction of the vein lumen & 10.0 & & 3.2 & & 16.8 & & 5.7 & & 22.4 & & 7.9 & & 27.4 & & 10.0 & \\
\hline $\begin{array}{l}\text { Average contact pressure at } \\
\text { skin-sock interface }\end{array}$ & 17.3 & \pm 5.3 & 17.4 & \pm 5.8 & 34.7 & \pm 9.3 & 34.7 & \pm 9.8 & 52.0 & \pm 12.9 & 52.0 & \pm 13.4 & 69.3 & \pm 16.6 & 69.4 & \pm 17.2 \\
\hline $\begin{array}{l}\text { Mean trans-mural pressure in } \\
\text { vein wall before EC }\end{array}$ & 11.0 & \pm 1.1 & 67.2 & \pm 5.4 & 11.0 & \pm 1.1 & 67.2 & \pm 5.4 & 11.0 & \pm 1.1 & 67.2 & \pm 5.4 & 11.0 & \pm 1.1 & 67.2 & \pm 5.4 \\
\hline $\begin{array}{l}\text { Mean decrease of trans-mural } \\
\text { pressure in vein wall due to } \\
\text { EC }\end{array}$ & 4.8 & \pm 2.5 & 12.3 & \pm 11.1 & 10.1 & \pm 4.5 & 23.7 & \pm 10.3 & 16.0 & \pm 8.3 & 34.8 & \pm 9.3 & 22.1 & \pm 14.4 & 45.8 & \pm 8.6 \\
\hline $\begin{array}{l}\text { Mean increase in hydrostatic } \\
\text { pressure in fat due to EC }\end{array}$ & 19.8 & \pm 3.7 & 19.9 & \pm 6.6 & 37.2 & \pm 6.3 & 38.3 & \pm 7.7 & 54.3 & \pm 9.2 & 56.2 & \pm 8.6 & 71.2 & \pm 12.8 & 73.7 & \pm 9.7 \\
\hline $\begin{array}{l}\text { Maximum hydrostatic } \\
\text { pressure in fat }\end{array}$ & 29.0 & & 39.3 & & 57.6 & & 59.8 & & 91.0 & & 91.1 & & 123.7 & & 119.9 & \\
\hline
\end{tabular}

Note: average results given as mean \pm standard deviation

Table A5: Effect of the applied external compression 


\begin{tabular}{|c|c|c|c|c|c|c|c|c|c|c|c|c|c|c|c|c|}
\hline $\mathrm{C}_{10}$ Fat $(\mathrm{kPa})$ & \multicolumn{4}{|l|}{3} & \multicolumn{4}{|l|}{5} & \multicolumn{4}{|l|}{6} & \multicolumn{4}{|l|}{7.5} \\
\hline \multirow{2}{*}{$\begin{array}{l}\text { Note : all pressures given in } \\
\text { mmHg }\end{array}$} & \multicolumn{4}{|c|}{ Configuration 1} & \multicolumn{4}{|c|}{ Reference configuration } & \multicolumn{4}{|c|}{ Configuration 2} & \multicolumn{4}{|c|}{ Configuration 3} \\
\hline & Supine & & Standin & & Supine & & Standin & & Supine & & Standin & & Supine & & Standing & \\
\hline reduction of the vein lumen & 12.2 & & 3.3 & & 10.0 & & 3.2 & & 9.2 & & 3.1 & & 8.3 & & 3.0 & \\
\hline $\begin{array}{l}\text { Average contact pressure at } \\
\text { skin-sock interface }\end{array}$ & 17.3 & \pm 4.9 & 28.7 & \pm 10.0 & 17.3 & \pm 5.3 & 17.4 & \pm 5.8 & 17.4 & \pm 5.5 & 17.4 & \pm 5.9 & 17.4 & \pm 5.7 & 17.3 & \pm 6.2 \\
\hline $\begin{array}{l}\text { Mean trans-mural pressure in } \\
\text { vein wall before EC }\end{array}$ & 11.0 & \pm 1.1 & 67.3 & \pm 5.4 & 11.0 & \pm 1.1 & 67.2 & \pm 5.4 & 11.0 & \pm 1.1 & 67.2 & \pm 5.4 & 11.0 & \pm 1.1 & 67.2 & \pm 5.4 \\
\hline $\begin{array}{l}\text { Mean decrease of trans-mural } \\
\text { pressure in vein wall due to } \\
\text { EC }\end{array}$ & 6.4 & \pm 2.4 & 12.9 & \pm 10.9 & 4.8 & \pm 2.5 & 12.3 & \pm 11.1 & 4.3 & \pm 2.6 & 11.9 & \pm 11.1 & 3.7 & \pm 2.6 & 11.4 & \pm 11.2 \\
\hline $\begin{array}{l}\text { Mean increase in hydrostatic } \\
\text { pressure in fat due to EC }\end{array}$ & 18.7 & \pm 3.0 & 19.1 & \pm 5.9 & 19.8 & \pm 3.7 & 19.9 & \pm 6.6 & 20.3 & \pm 4.1 & 20.2 & \pm 6.8 & 20.9 & \pm 4.7 & 20.5 & \pm 7.1 \\
\hline $\begin{array}{l}\text { Maximum hydrostatic } \\
\text { pressure in fat }\end{array}$ & 27.6 & & 36.1 & & 29.0 & & 39.3 & & 29.9 & & 40.4 & & 32.1 & & 42.4 & \\
\hline
\end{tabular}

Note: average results given as mean \pm standard deviation

Table A6: Influence of the "type" of fat for the stiffness 


\begin{tabular}{|c|c|c|c|c|c|c|c|c|c|c|c|c|c|c|c|c|}
\hline $\mathrm{D}_{1}$ Fat $\left(\mathrm{MPa}^{-1}\right)$ & \multicolumn{4}{|l|}{0.005} & \multicolumn{4}{|l|}{0.14} & \multicolumn{4}{|l|}{1} & \multicolumn{4}{|l|}{10} \\
\hline \multirow{2}{*}{$\begin{array}{l}\text { Note : all pressures given in } \\
\text { mmHg }\end{array}$} & \multicolumn{4}{|c|}{ Configuration 1} & \multicolumn{4}{|c|}{ Reference configuration } & \multicolumn{4}{|c|}{ Configuration 2} & \multicolumn{4}{|c|}{ Configuration 3} \\
\hline & Supine & & Standin & & Supine & & Standin & & Supine & & Standin & & Supine & & Standing & \\
\hline reduction of the vein lumen & 10.0 & & 3.2 & & 10.0 & & 3.2 & & 10.0 & & 3.2 & & 10.0 & & 3.2 & \\
\hline $\begin{array}{l}\text { Average contact pressure at } \\
\text { skin-sock interface }\end{array}$ & 17.4 & \pm 5.4 & 17.4 & \pm 5.9 & 17.3 & \pm 5.3 & 17.4 & \pm 5.8 & 17.4 & \pm 5.4 & 17.3 & \pm 5.8 & 17.3 & \pm 5.3 & 17.3 & \pm 5.4 \\
\hline $\begin{array}{l}\text { Mean trans-mural pressure in } \\
\text { vein wall before EC }\end{array}$ & 11.0 & \pm 1.1 & 67.4 & \pm 5.4 & 11.0 & \pm 1.1 & 67.2 & \pm 5.4 & 11.0 & \pm 1.1 & 67.2 & \pm 5.4 & 11.0 & \pm 1.1 & 67.2 & \pm 5.4 \\
\hline $\begin{array}{l}\text { Mean decrease of trans-mural } \\
\text { pressure in vein wall due to } \\
\text { EC }\end{array}$ & 4.8 & \pm 2.5 & 12.2 & \pm 11.1 & 4.8 & \pm 2.5 & 12.3 & \pm 11.1 & 4.8 & \pm 2.5 & 12.3 & \pm 11.1 & 4.7 & \pm 2.7 & 12.0 & \pm 11.2 \\
\hline $\begin{array}{l}\text { Mean increase in hydrostatic } \\
\text { pressure in fat due to EC }\end{array}$ & 19.8 & \pm 3.8 & 19.9 & \pm 6.6 & 19.8 & \pm 3.7 & 19.9 & \pm 6.6 & 19.6 & \pm 3.7 & 19.8 & \pm 6.6 & 18.4 & \pm 3.6 & 18.4 & \pm 6.1 \\
\hline $\begin{array}{l}\text { Maximum hydrostatic } \\
\text { pressure in fat }\end{array}$ & 29.1 & & 39.1 & & 29.0 & & 39.3 & & 28.5 & & 38.9 & & 26.4 & & 36.1 & \\
\hline
\end{tabular}

Note: average results given as mean \pm standard deviation

Table A7: Influence of the "type" of fat for the incompressibility parameter 


\begin{tabular}{|c|c|c|c|c|c|c|c|c|}
\hline $\begin{array}{l}\text { Constitutive behaviour law } \\
\text { for the vein wall }\end{array}$ & \multicolumn{4}{|c|}{ Bi-linear elastic model } & \multicolumn{4}{|c|}{$\begin{array}{l}\text { Neo-Hookean material } \\
\text { behaviour law }\end{array}$} \\
\hline \multirow{2}{*}{$\begin{array}{l}\text { Note : all pressures given in } \\
\mathrm{mmHg}\end{array}$} & \multicolumn{8}{|c|}{ Reference configuration } \\
\hline & Supine & & Standin & & Supine & & Standin & \\
\hline reduction of the vein lumen & 10.0 & & 3.2 & & 9.8 & & 3.2 & \\
\hline skin-sock interface & 17.3 & \pm 5.3 & 17.4 & \pm 5.8 & 17.3 & \pm 5.3 & 17.3 & \pm 5.8 \\
\hline $\begin{array}{l}\text { Mean trans-mural pressure in } \\
\text { vein wall before EC }\end{array}$ & 11.0 & \pm 1.1 & 67.2 & \pm 5.4 & 11.0 & \pm 1.3 & 67.1 & \pm 6.6 \\
\hline $\begin{array}{l}\text { Mean decrease of trans-mural } \\
\text { pressure in vein wall due to } \\
\text { EC }\end{array}$ & 4.8 & \pm 2.5 & 12.3 & \pm 11.1 & 5.3 & \pm 2.7 & 12.2 & \pm 12.4 \\
\hline $\begin{array}{l}\text { Mean increase in hydrostatic } \\
\text { pressure in fat due to EC }\end{array}$ & 19.8 & \pm 3.7 & 19.9 & \pm 6.6 & 19.8 & \pm 3.7 & 19.9 & \pm 6.5 \\
\hline $\begin{array}{l}\text { Maximum hydrostatic } \\
\text { pressure in fat }\end{array}$ & 29.0 & & 39.3 & & 29.0 & & 39.2 & \\
\hline
\end{tabular}

Note: average results given as mean \pm standard deviation

Table 8A: 


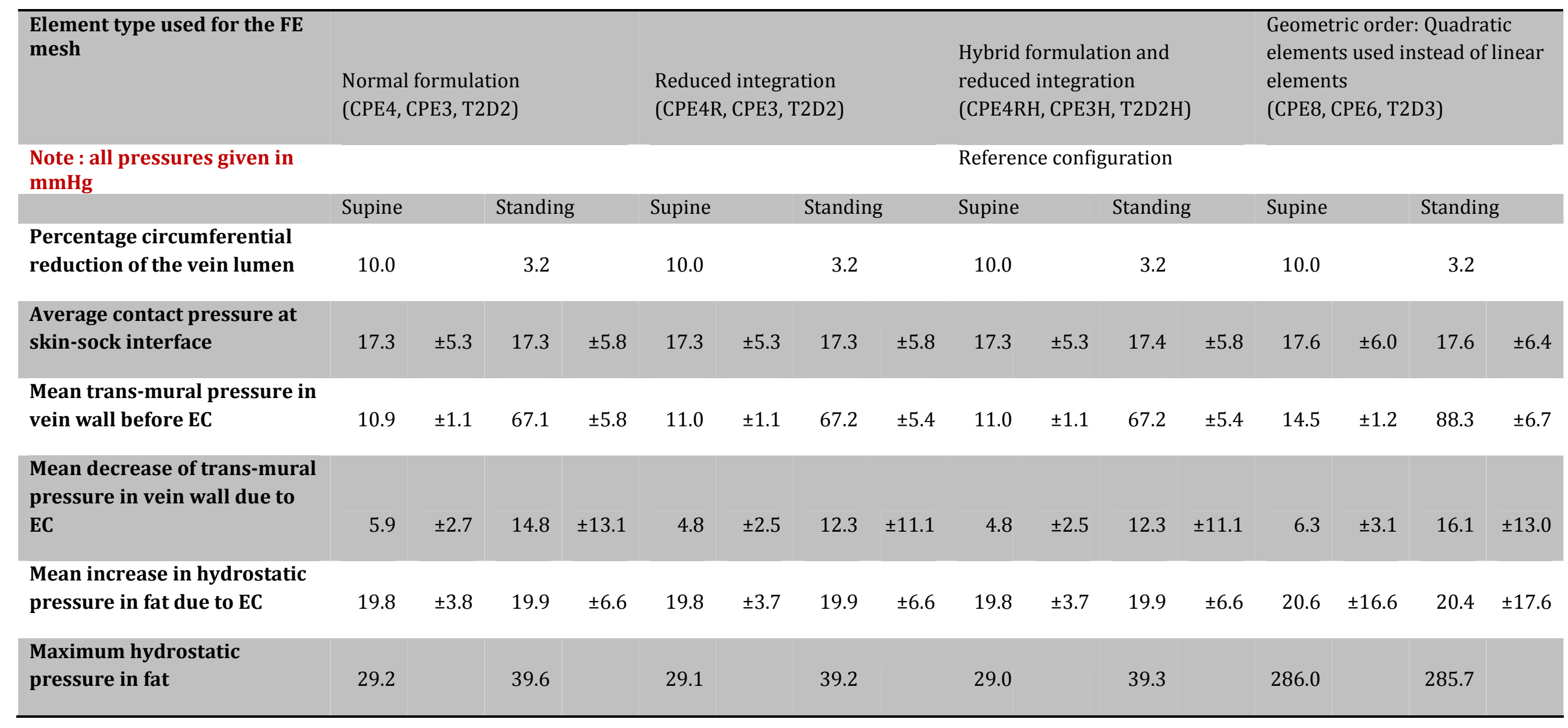

Note: average results given as mean \pm standard deviation

Table A9 


\begin{tabular}{|c|c|c|c|c|c|c|c|c|c|c|c|c|c|c|c|c|}
\hline \multirow{3}{*}{$\begin{array}{l}\text { Contact formulation for the } \\
\text { interface Fat/Vein } \\
\text { Note : all pressures given in } \\
\mathrm{mmHg}\end{array}$} & \multicolumn{4}{|c|}{ Tie constraint } & \multicolumn{4}{|c|}{ Frictionless } & \multicolumn{4}{|c|}{$\begin{array}{l}\text { Friction - "Hard" contact } \\
\text { contact pressure-overclosure } \\
\text { relationship }\end{array}$} & \multicolumn{4}{|c|}{$\begin{array}{l}\text { Friction - Exponential ("Soft") } \\
\text { contact pressure-overclosure } \\
\text { relationship }\end{array}$} \\
\hline & \multicolumn{16}{|c|}{ Reference configuration } \\
\hline & Supine & & Standing & & Supine & & Standing & & Supine & & Standin & & Supine & & Standin & \\
\hline $\begin{array}{l}\text { Percentage circumferential } \\
\text { reduction of the vein lumen }\end{array}$ & 9.9 & & 3.1 & & 10.1 & & 3.2 & & 10.1 & & 3.1 & & 10.1 & & 3.2 & \\
\hline $\begin{array}{l}\text { Average contact pressure at } \\
\text { skin-sock interface }\end{array}$ & 17.3 & \pm 5.3 & 17.4 & \pm 5.8 & 17.3 & \pm 5.3 & 17.4 & \pm 5.8 & 17.3 & \pm 5.3 & 17.4 & \pm 5.8 & 17.3 & \pm 5.3 & 17.4 & \pm 5.8 \\
\hline $\begin{array}{l}\text { Mean trans-mural pressure in } \\
\text { vein wall before EC }\end{array}$ & 11.0 & \pm 1.1 & 67.2 & \pm 5.4 & 10.8 & \pm 1.1 & 67.2 & \pm 5.4 & 10.9 & \pm 1.1 & 67.2 & \pm 5.4 & 9.8 & \pm 0.9 & 64.6 & \pm 5.1 \\
\hline $\begin{array}{l}\text { Mean decrease of trans-mural } \\
\text { pressure in vein wall due to } \\
\text { EC }\end{array}$ & 4.7 & \pm 2.5 & 12.0 & \pm 11.0 & 5.2 & \pm 2.3 & 12.8 & \pm 12.0 & 5.1 & \pm 1.9 & 12.4 & \pm 11.3 & 5.6 & \pm 1.6 & 12.7 & \pm 10.6 \\
\hline $\begin{array}{l}\text { Mean increase in hydrostatic } \\
\text { pressure in fat due to EC }\end{array}$ & 19.5 & \pm 3.7 & 19.7 & \pm 6.5 & 19.9 & \pm 4.8 & 20.0 & \pm 4.9 & 19.8 & \pm 4.5 & 19.8 & \pm 5.5 & 20.0 & \pm 4.6 & 20.1 & \pm 5.6 \\
\hline $\begin{array}{l}\text { Maximum hydrostatic } \\
\text { pressure in fat }\end{array}$ & 36.5 & & 39.4 & & 35.2 & & 35.6 & & 34.9 & & 37.0 & & 29.8 & & 38.0 & \\
\hline
\end{tabular}

Note: average results given as mean \pm standard deviation

Table A10 


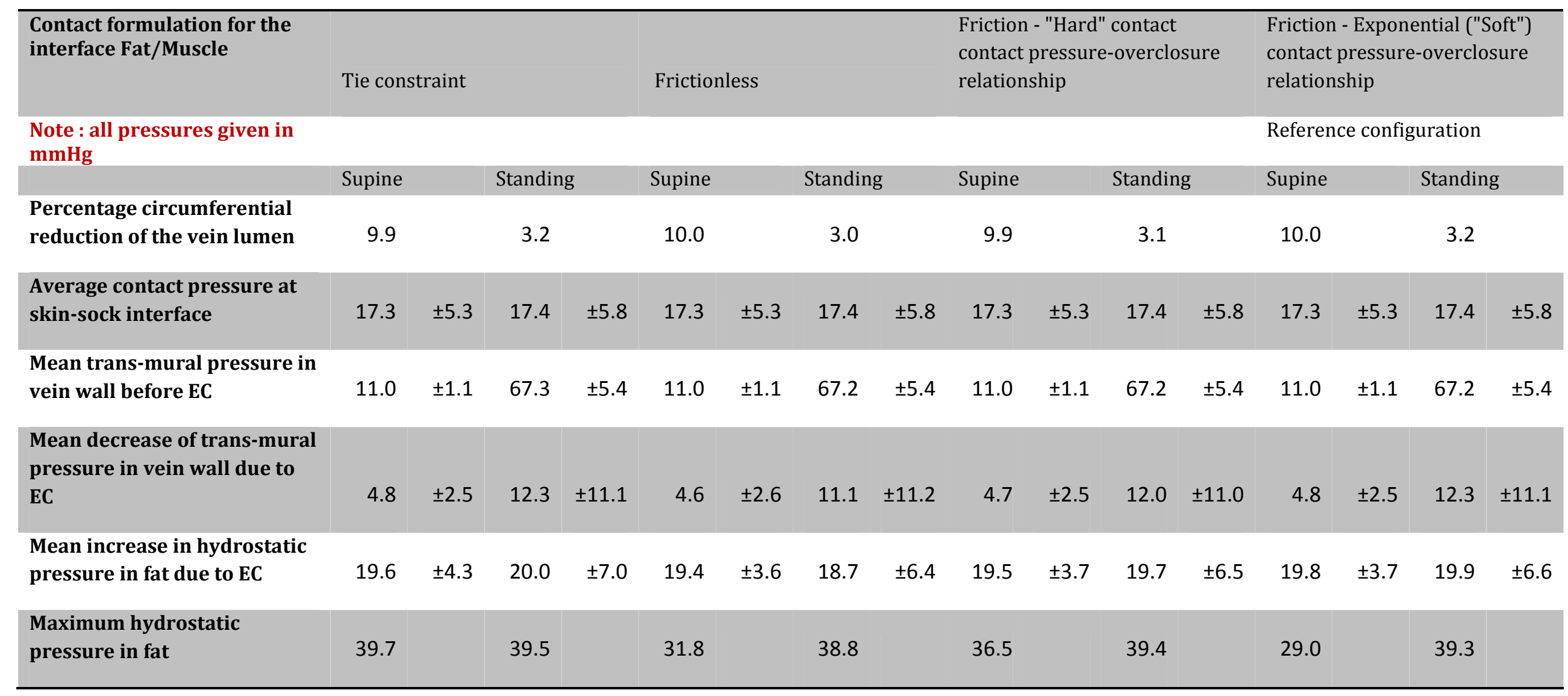

Note: average results given as mean \pm standard deviation

Table A11 


\begin{tabular}{|c|c|c|c|c|c|c|c|c|c|c|c|c|c|}
\hline $\begin{array}{l}\text { Contact formulation for the } \\
\text { interface Skin/MCS }\end{array}$ & \multicolumn{5}{|l|}{ Tie constraint } & \multicolumn{4}{|c|}{$\begin{array}{l}\text { Friction - "Hard" contact } \\
\text { contact pressure-overclosure } \\
\text { relationship }\end{array}$} & \multicolumn{4}{|c|}{$\begin{array}{l}\text { Friction - Exponential ("Soft") } \\
\text { contact pressure-overclosure } \\
\text { relationship }\end{array}$} \\
\hline Note : all pressures given in & & & & \multirow{2}{*}{\multicolumn{2}{|c|}{ Standing }} & & & & & \multicolumn{4}{|c|}{ Reference configuration } \\
\hline & Standing & Supine & & & & Supine & & Standin & & Supine & & Standin & \\
\hline reduction of the vein lumen & \multirow{6}{*}{$\begin{array}{l}\text { Not relevant because loading of } \\
\text { the leg is done by simulating } \\
\text { the contact between the MCS } \\
\text { and the skin }\end{array}$} & 10.0 & & 3.0 & & 9.9 & & 3.1 & & 10.0 & & 3.2 & \\
\hline $\begin{array}{l}\text { Average contact pressure at } \\
\text { skin-sock interface }\end{array}$ & & 17.3 & \pm 5.3 & 17.4 & \pm 5.8 & 18.8 & \pm 23.3 & 18.8 & \pm 23.5 & 17.3 & \pm 5.3 & 17.4 & \pm 5.8 \\
\hline $\begin{array}{l}\text { Mean trans-mural pressure in } \\
\text { vein wall before EC }\end{array}$ & & 11.0 & \pm 1.1 & 67.2 & \pm 5.4 & 11.0 & \pm 1.1 & 67.2 & \pm 5.4 & 11.0 & \pm 1.1 & 67.2 & \pm 5.4 \\
\hline $\begin{array}{l}\text { Mean decrease of trans-mural } \\
\text { pressure in vein wall due to } \\
\text { EC }\end{array}$ & & 4.6 & \pm 2.6 & 11.1 & \pm 11.2 & 4.7 & \pm 2.5 & 12.0 & \pm 11.0 & 4.8 & \pm 2.5 & 12.3 & \pm 11.1 \\
\hline $\begin{array}{l}\text { Mean increase in hydrostatic } \\
\text { pressure in fat due to EC }\end{array}$ & & 19.4 & \pm 3.6 & 18.7 & \pm 6.4 & 19.5 & \pm 3.7 & 19.7 & \pm 6.5 & 19.8 & \pm 3.7 & 19.9 & \pm 6.6 \\
\hline $\begin{array}{l}\text { Maximum hydrostatic } \\
\text { pressure in fat }\end{array}$ & & 31.8 & & 38.8 & & 36.5 & & 39.4 & & 29.0 & & 39.3 & \\
\hline
\end{tabular}

Note: average results given as mean \pm standard deviation

Table A12 